\title{
(2) OPEN ACCESS \\ Association between fine particulate matter and oral cancer among Taiwanese men
}

\author{
Yu-Hua Chu, ${ }^{1,2,3}$ Syuan-Wei Kao, ${ }^{4}$ Disline Manli Tantoh, ${ }^{4}$ Pei-Chieh Ko, ${ }^{4}$ \\ Shou-Jen Lan, ${ }^{1,5}$ Yung-Po Liaw ${ }^{4,6}$
}

${ }^{1}$ Department of Healthcare Administration, Asia University, Taichung City, Taiwan

${ }^{2} \mathrm{School}$ of Dentistry, National Defense Medical Center, Taipei City, Taiwan ${ }^{3}$ Department of Dental Technology and Materials Science, Central Taiwan University of Science and Technology, Taichung City, Taiwan

${ }^{4}$ Department of Public Health and Institute of Public Health, Chung Shan Medical University, Taichung City, Taiwan

${ }^{5}$ Department of Medical Research, China Medical Hospital, China Medical University, Taichung City, Taiwan

${ }^{6}$ Department of Family and Community Medicine, Chung Shan Medical University Hospital, Taichung City, Taiwan

\section{Correspondence to} Professor Shou-Jen Lan, Department of Healthcare Administration, Asia University, Taichung City, 413, Taiwan:

sjlan@asia.edu.tw and Professor Yung-Po Liaw, Department of Public Health and Institute of Public Health, Chung Shan Medical University, Taichung City, 40201, Taiwan;

Liawyp@csmu.edu.tw

Accepted 18 July 2018 Published Online First 9 October 2018

\section{Check for updates}

(C) American Federation for Medical Research 2019. Re-use permitted under CC BY-NC. No commercial re-use. Published by BMJ.

To cite: Chu Y-H, Kao S-W, Tantoh DM, et al. J Investig Med 2019;67:34-38.

\section{ABSTRACT}

The aim of this study was to investigate the association between fine particulate matter $2.5\left(\mathrm{PM}_{25}\right)$ and oral cancer among Taiwanese men. Four linked data sources including the Taiwan Cancer Registry, Adult Preventive Medical Services Database, National Health Insurance Research Database, and Air Quality Monitoring Database were used. Concentrations of sulfur dioxide, carbon monoxide, ozone, NOx (nitrogen monoxide and nitrogen dioxide), coarse particulate matter $\left(\mathrm{PM}_{10-2.5}\right)$ and $\mathrm{PM}_{2.5}$ in 2009 were assessed in quartiles. A total of 482659 men aged 40 years and above were included in the analysis. Logistic regression was used to examine the association between $\mathrm{PM}_{2.5}$ and oral cancer diagnosed from 2012 to 2013. After adjusting for potential confounders, the ORs of oral cancer were $0.91(95 \% \mathrm{Cl} 0.75$ to 1.11) for $26.74 \leq \mathrm{PM}_{25}<32.37,1.01$ ( $95 \% \mathrm{Cl} 0.84$ to 1.20) for $32.37 \leq \mathrm{PM}_{25}<40.37 \mu \mathrm{g} / \mathrm{m}^{3}$ and $1.43(95 \%$ Cl 1.17 to 1.74 ) for $\mathrm{PM}_{2.5} \geq 40.37 \mu \mathrm{g} / \mathrm{m}^{3}$ compared with $\mathrm{PM}_{2.5}<26.74 \mu \mathrm{g} / \mathrm{m}^{3.5}$. In this study, there was an increased risk of oral cancer among Taiwanese men who were exposed to higher concentrations of $\mathrm{PM}_{2.5}$.

\section{INTRODUCTION}

Oral cancer is a serious and growing problem in many parts of the world. ${ }^{1}$ In 2012, the global incidence and deaths resulting from oral cancer were estimated at 300000 and 145000 , respectively. ${ }^{2}$ A study reported an increase in the incidence of oral cancer among Taiwanese men. ${ }^{3}$ Betel quid chewing, smoking, drinking, and human papillomavirus (HPV) have been associated with an increased risk of oral cancer. ${ }^{4-7}$

Exposure to heavy metals like arsenic, nickel, and chromium especially at higher concentrations, as well as emissions from petroleum and chemical plants have been shown to increase the risk of oral cancer. ${ }^{8-10}$ Particulate matter less than or equal to 2.5 microns in diameter $\left(\mathrm{PM}_{2.5}\right)$ is harmful to human health, contributing to respiratory and cardiovascular diseases. ${ }^{11-13}$ This risk is partly because $\mathrm{PM}_{2.5}$ can be inhaled into the lungs and bronchi, owing to its small size. ${ }^{14}$ Long-term and shortterm exposures to $\mathrm{PM}_{25}$ have also been linked to increased hospital admissions and cardiovascular mortality. ${ }^{12}{ }^{15}$ However, few studies have been conducted to investigate the relationship between $\mathrm{PM}_{2.5}$ and oral cancer. The aim of this

\section{Significance of this study}

What is already known about this subject?

- Exposure to particulate matter $2.5\left(\mathrm{PM}_{2.5}\right)$ is associated with an increased risk of cardiovascular diseases and lung cancer.

- The oral cavity is one of the routes by which $\mathrm{PM}_{2.5}$ gains access into the lungs and alveoli.

- The incidence of oral cancer among Taiwanese men is increasing.

- Some of the known risk factors for oral cancer are betel quid chewing, smoking, and drinking.

\section{What are the new findings?}

- When compared with $\mathrm{PM}_{2.5}<26.74 \mu \mathrm{g} / \mathrm{m}^{3}$, $\mathrm{PM}_{2.5} \geq 40.37 \mu \mathrm{g} / \mathrm{m}^{3}$ was significantly associated with an increased risk of oral cancer.

- Ozone $\left(28.69 \leq \mathrm{O}_{3}<30.97 \mathrm{ppb}\right)$ was significantly associated with an increased risk of oral cancer.

- Smoking and frequent betel quid chewing were significantly associated with an increased risk of oral cancer.

How might these results change the focus of research or clinical practice?

- These results have increased knowledge regarding fine particulate pollution as a risk factor for oral cancer.

- This study indicates the need for further research to investigate the association between oral cancer and $\mathrm{PM}_{2.5^{\prime}}$ including lower exposure levels.

study was to investigate the association between $\mathrm{PM}_{2.5}$ and oral cancer among Taiwanese men.

\section{MATERIALS AND METHODS \\ Data sources}

Four data sources which included the Taiwan Cancer Registry (TCR), Adult Preventive Medical Services Database (APMSD), National Health Insurance Research Database (NHIRD), and the Air Quality Monitoring Database (AQMD) were used in this study. The data sets were linked using personal identification 
numbers of the participants which were protected for privacy reasons.

\section{Air pollutants}

Air pollution data were retrieved from the AQMD which had been set up by the Environmental Protection Administration of the Executive Yuan. This database contains daily concentrations of pollutants collected from fully automated air quality monitoring stations. The data are available from 1998 through 2011. Nonetheless, data on PM $_{25}$ are available only from 2006. The air pollution data used in this study were collected from 66 air quality monitoring stations located in 64 different municipalities. Two municipalities had two monitoring stations each, while the other $62 \mathrm{had}$ only one station each.

The annual average concentrations of sulfur dioxide $\left(\mathrm{SO}_{2}\right)$, carbon monoxide $(\mathrm{CO})$, ozone $\left(\mathrm{O}_{3}\right)$, NOx (nitrogen monoxide (NO), nitrogen dioxide $\left.\left(\mathrm{NO}_{2}\right)\right), \mathrm{PM}_{10}, \mathrm{PM}_{2.5}$, and $\mathrm{PM}_{10-2.5}$ in 2009 were determined. The $\mathrm{PM}_{10-2.5}$ concentration was determined by subtracting the concentration of $\mathrm{PM}_{2.5}$ from that of $\mathrm{PM}_{10}$. The pollution levels in 2009 were selected, because this year marked the midpoint of the available $\mathrm{PM}_{2,5}$ pollution data. To draw inferences regarding pre-2006 $\mathrm{PM}_{2.5}$ exposure trends, we examined the correlation between $\mathrm{PM}_{10}$ and $\mathrm{PM}_{2.5}$ in the years that data on both pollutants were available.

\section{Study participants and measures}

Since 1996, adults in Taiwan have enjoyed free preventive medical services. Valid electronic records of persons who use the services were established only in 2012. These records are maintained by the Health Promotion Administration of the Ministry of Health and Welfare.

The study participants included men aged 40 years and older who lived in the 64 different municipalities. Birthdate and gender were retrieved from the NHIRD. Age was determined by subtracting the birthdate found in the NHIRD from the enrollment date found in the 2012-2013 APMSD. Air pollution exposure was assigned based on the participants' household registration municipality in the NHIRD. Data on smoking and betel chewing were only available from 2012 and 2013. Hence, the study participants (both cases and controls) were restricted to those who attended the adult preventive medical services in 2012 or 2013 and provided information on smoking and betel chewing. This information was obtained by asking participants whether they have ever chewed betel quid or smoked cigarettes. Those whose response was 'no' were considered as never chewers/smokers. For those whose response was 'yes', they were further asked how often they chewed betel quid or smoked cigarettes. Those whose response was 'almost every day' were defined as frequent chewers/smokers, while those whose response was 'sometimes or on social occasions' were defined as occasional chewers/smokers.

Oral cancer data diagnosed from 2012 to 2013 were collected from the TCR. The International Classification of Diseases Oncology, third version codes used included C00C06, C09-C10, and C12-C14. Persons with incomplete personal information were excluded from the study. A total of 482659 participants were included in the final analysis.

\section{Statistical analysis}

Data were analyzed using SAS V.9.4. Pearson correlation was used to assess the correlation among air pollutants (CO, NOx, $\mathrm{O}_{3}, \mathrm{PM}_{10}, \mathrm{PM}_{10-2.5}, \mathrm{PM}_{2.5}$, and $\mathrm{SO}_{2}$ ), while Spearman's correlation was used to assess the $\mathrm{PM}_{2.5}$ correlation from 2006 to 2011. The collinearity of the air pollutants with $\mathrm{PM}_{2.5}$ was determined and the variance influence factors $>10$ were deleted from the regression analysis. Logistic regression analysis was used to assess the relationship between $\mathrm{PM}_{2.5}$ and oral cancer. Concentrations of air pollutants were stratified into quartiles. $\mathrm{PM}_{2.5}<26.74 \mu \mathrm{g} / \mathrm{m}^{3}$ (Q1) was set as the reference. The ORs and 95\% CI were determined and $\mathrm{p}<0.05$ was considered statistically significant. Adjustments were made for $\mathrm{PM}_{10-2.5}, \mathrm{SO}_{2}, \mathrm{O}_{3}$, age, betel quid chewing, and smoking.

\section{RESULTS}

The concentrations of the air pollutants are shown in table 1. For $\mathrm{PM}_{2.5}$, Q1, median and Q3 were 26.74, 32.37, and $40.37 \mu \mathrm{g} / \mathrm{m}^{3}$, respectively. The correlation among the air pollutants is shown in table 2. After checking for collinearity of the other air pollutants with $\mathrm{PM}_{2.5}$, the variance influence factors for $\mathrm{CO}$ and $\mathrm{NOx}$ were $>10$ (table not shown) and they were therefore deleted from the regression analysis. The descriptive data of the participants are shown in table 3 . There were 1617 oral cancer cases (mean age $=60.69 \pm 10.89$ years) and 481042 non-oral cancer cases (mean age $=61.2 \pm 12.77$ years). The mean ages of cases and non-cases were not significantly different.

Table 4 presents the association of oral cancer with $\mathrm{PM}_{2.5}$ after multivariable adjustments. The ORs of oral cancer were 0.91 (95\% CI 0.75 to 1.10 ) for $26.74 \leq \mathrm{PM}_{2.5}<32.37$, $1.00 \quad(95 \%$ CI 0.84 to 1.20$)$ for $32.37 \leq \mathrm{PM}_{2.5}$ $<40.37 \mu \mathrm{g} / \mathrm{m}^{3}$ and $1.42(95 \% \mathrm{CI} 1.17$ to 1.73$)$ for $\mathrm{PM}_{2.5} \geq 40.37 \mu \mathrm{g} / \mathrm{m}^{3}$ after adjusting for $\mathrm{PM}_{10-2.5}, \mathrm{SO}_{2}, \mathrm{O}_{3}$,

Table 1 Concentrations of air pollutants in Taiwan (2009)

\begin{tabular}{llrrrrrrr}
\hline Air pollutants & Unit & Mean & Q1 & Median & Q3 & Min. & Max. & Range \\
\hline Carbon monoxide & $\mathrm{ppm}$ & 0.47 & 0.36 & 0.43 & 0.53 & 0.17 & 1.29 & 1.12 \\
Nitrogen oxides & $\mathrm{ppb}$ & 22.06 & 15.17 & 20.42 & 26.55 & 3.64 & 80.71 & 77.07 \\
Sulfur dioxide & $\mathrm{ppb}$ & 4.11 & 2.96 & 3.61 & 4.43 & 1.82 & 11.43 & 9.60 \\
Ozone & $\mathrm{ppb}$ & 30.88 & 28.69 & 30.97 & 33.79 & 21.67 & 43.88 & 22.21 \\
$\mathrm{PM}_{2.5}$ & $\mu \mathrm{g} / \mathrm{m}^{3}$ & 33.10 & 26.74 & 32.37 & 40.37 & 13.79 & 50.30 & 36.51 \\
$\mathrm{PM}_{10}$ & $\mu \mathrm{g} / \mathrm{m}^{3}$ & 58.93 & 47.15 & 56.04 & 74.51 & 26.74 & 93.69 & 66.95 \\
$\mathrm{PM}_{10-2.5 \dagger}$ & $\mu \mathrm{g} / \mathrm{m}^{3}$ & 25.87 & 18.97 & 23.82 & 32.68 & 11.57 & 49.70 & 38.13 \\
\hline
\end{tabular}

$\mathrm{PM}$, particulate matter.

tPM $\mathrm{P}_{10}$ minus $\mathrm{PM}_{2.5^{\circ}}$. 
Table 2 Correlation among air pollutants (CO, NOx, 03, PM10, PM2.5, SO2, and PM10-2.5) using Spearman's analysis

\begin{tabular}{|c|c|c|c|c|c|c|c|}
\hline Pollutants & $\mathrm{CO}$ & NOx & $\mathrm{O}_{3}$ & $\mathrm{PM}_{10}$ & $\mathrm{PM}_{2.5}$ & $\mathrm{SO}_{2}$ & $\mathrm{PM}_{10-2.5}$ \\
\hline $\mathrm{CO}$ & 1.000 & $0.945^{*}$ & $-0.570^{*}$ & $0.040^{*}$ & $0.068^{*}$ & $0.196^{*}$ & $-0.004^{*}$ \\
\hline NOx & - & 1.000 & $-0.547^{*}$ & $0.057^{*}$ & $0.105^{*}$ & $0.232^{*}$ & $-0.017^{*}$ \\
\hline $\mathrm{O}_{3}$ & - & - & 1.000 & $0.249^{*}$ & $0.141^{*}$ & $-0.083^{*}$ & $0.307^{*}$ \\
\hline $\mathrm{PM}_{10}$ & - & - & - & 1.000 & $0.892^{*}$ & $0.495^{*}$ & $0.843^{*}$ \\
\hline $\mathrm{PM}_{2.5}$ & - & - & - & - & 1.000 & $0.418^{*}$ & $0.508^{*}$ \\
\hline $\mathrm{SO}_{2}$ & - & - & - & - & - & 1.000 & $0.446^{*}$ \\
\hline $\mathrm{PM}_{10-2.5 t}$ & - & - & - & - & - & - & 1.000 \\
\hline
\end{tabular}

$\mathrm{CO}$, carbon monoxide; $\mathrm{NOx}$, nitrogen oxides; $\mathrm{O}_{3^{\prime}}$ ozone; $\mathrm{PM}$, particulate matter; $\mathrm{SO}_{2}$, sulfur dioxide.

${ }^{*} \mathrm{P}<0.05$.

$\mathrm{TPM}_{10}$ minus $\mathrm{PM}_{2.5}$.

age, and betel quid chewing (table 4, Model 1). After a further adjustment including smoking (table 4, Model 2), the effect of $\mathrm{PM}_{25}$ on oral cancer risk did not change. In both models, $\mathrm{PM}_{10-2.5}$ and $\mathrm{SO}_{2}$ had no significant association with oral cancer regardless of their concentrations. However, $\mathrm{O}_{3}$, frequent betel quid chewing, occasional, as well as frequent smoking were significantly associated with oral cancer (table 4, Models 1 and 2). Spearman's analysis showed that $\mathrm{PM}_{2.5}$ concentrations were highly correlated from 2006 to 2011 (table 5).

\begin{tabular}{|c|c|c|c|}
\hline Variable & $\begin{array}{l}\text { Non-oral cancer } \\
\text { cases }(n=481042)\end{array}$ & $\begin{array}{l}\text { Oral cancer } \\
\text { cases }(n=1617)\end{array}$ & $P$ values \\
\hline \multicolumn{4}{|l|}{$\mathrm{PM}_{2.5}$} \\
\hline $\mathrm{PM}_{2.5}<26.74$ & $110752(23.02)$ & $356(22.02)$ & \multirow[t]{4}{*}{$<0.0001^{*}$} \\
\hline $26.74 \leq \mathrm{PM}_{2.5}<32.37$ & $152790(31.76)$ & $432(26.72)$ & \\
\hline $32.37 \leq \mathrm{PM}_{2.5}<40.37$ & $109291(22.72)$ & $330(20.41)$ & \\
\hline $\mathrm{PM}_{2.5} \geq 40.37$ & 108209 (22.49) & $499(30.86)$ & \\
\hline \multicolumn{4}{|l|}{$\mathrm{PM}_{10-2.5}{ }^{\dagger}$} \\
\hline $\mathrm{PM}_{10-2.5}<18.88$ & $115603(24.03)$ & $351(21.71)$ & \multirow[t]{4}{*}{$<0.0001^{*}$} \\
\hline $18.88 \leq \mathrm{PM}_{10-2.5}<23.66$ & $141381(29.39)$ & $408(25.23)$ & \\
\hline $23.66 \leq \mathrm{PM}_{10-2.5}<32.42$ & $141433(29.4)$ & $524(32.41)$ & \\
\hline $\mathrm{PM}_{10-25} \geq 32.42$ & 82625 (17.18) & $334(20.66)$ & \\
\hline \multicolumn{4}{|l|}{$\mathrm{SO}_{2}$} \\
\hline $\mathrm{SO}_{2}<2.96$ & 74999 (15.59) & $269(16.64)$ & \multirow[t]{4}{*}{$<0.0001^{*}$} \\
\hline $2.96 \leq \mathrm{SO}_{2}<3.61$ & 138189 (28.73) & $380(23.5)$ & \\
\hline $3.61 \leq \mathrm{SO}_{2}<4.43$ & $134173(27.89)$ & $497(30.74)$ & \\
\hline $\mathrm{SO}_{2} \geq 4.43$ & 133681 (27.79) & $471(29.13)$ & \\
\hline \multicolumn{4}{|l|}{$\mathrm{O}_{3}$} \\
\hline $\mathrm{O}_{3}<28.69$ & $198106(41.18)$ & $583(36.05)$ & \multirow[t]{4}{*}{$<0.0001^{*}$} \\
\hline $28.69 \leq 0_{3}<30.97$ & $146672(30.49)$ & $567(35.06)$ & \\
\hline $30.97 \leq 0_{3}<33.79$ & 74951 (15.58) & $235(14.53)$ & \\
\hline $\mathrm{O}_{3} \geq 33.79$ & $61313(12.75)$ & $232(14.35)$ & \\
\hline Age (mean $\pm S D)$ & $61.2 \pm 12.77$ & $60.69 \pm 10.89$ & 0.0614 \\
\hline \multicolumn{4}{|l|}{ Betel chewing (\%) } \\
\hline Never & 444633 (92.43) & $1456(90.04)$ & \multirow[t]{3}{*}{$<0.0001^{*}$} \\
\hline Occasional & $22631(4.70)$ & 79 (4.89) & \\
\hline Frequent & $13778(2.86)$ & $82(5.07)$ & \\
\hline \multicolumn{4}{|l|}{ Smoking (\%) } \\
\hline Never & $366597(76.21)$ & $1131(69.94)$ & \multirow[t]{3}{*}{$<0.0001^{*}$} \\
\hline Occasional & 84315 (17.53) & 341 (21.09) & \\
\hline Frequent & $30130(6.26)$ & $145(8.97)$ & \\
\hline
\end{tabular}

$\mathrm{PM}$, particulate matter; $\mathrm{SO}_{2}$, sulfur dioxide.

${ }^{*} \mathrm{P}<0.05$.

$\mathrm{TPM}_{10}$ minus $\mathrm{PM}_{2.5}$.

\section{DISCUSSION}

This study, with a large sample size, is the first to associate oral cancer with $\mathrm{PM}_{2.5}$ using the aforementioned databases. After adjusting for the potential confounders, higher concentrations of $\mathrm{PM}_{2.5}\left(\geq 40.37 \mu \mathrm{g} / \mathrm{m}^{3}\right)$ were significantly associated with oral cancer in Taiwanese men. These findings add to the growing evidence on the adverse effects of $\mathrm{PM}_{2.5}$ on human health. ${ }^{11-13}$ The adverse health effects of $\mathrm{PM}_{2.5}$ could be linked to its relatively smaller diameter, yet a larger surface area which may potentially facilitate the adsorption and condensation of higher concentration of toxic substances and other pollutants. ${ }^{16}{ }^{17}$ Some of the components of $\mathrm{PM}_{2.5}$ including metals like lead, cadmium, arsenic, chromium, and nickel, as well as organic compounds like polycyclic aromatic hydrocarbons (PAHs), among others ${ }^{17-19}$ are carcinogenic. For instance, exposure to heavy metal pollutants like arsenic, nickel, and chromium has been associated with oral cancer risk. ${ }^{89}$ Moreover, exposure to asbestos and PAHs adsorbed on $\mathrm{PM}_{2.5}$ is reported to have increased the risk of oral cancer. ${ }^{20.5}$ The carcinogenicity of $\mathrm{PM}_{2.5}$ has been linked to oxidative DNA damage, metabolism of organic compounds as well as inflammatory injury. ${ }^{16} 182122$ Undetoxified carcinogenic substances and unrepaired damaged DNA, as well as replication of damaged DNA can aggravate carcinogenicity. ${ }^{23} 24$

In the current study, $\mathrm{O}_{3}$ was significantly associated with an increased risk of oral cancer. The deleterious effects of ozone on the respiratory tract are well known. ${ }^{25}$ Nonetheless, ozone was inversely associated with oral cancer risk though not statistically significant. ${ }^{26}$ Besides $\mathrm{O}_{3}$, smoking and betel quid chewing were associated with an increased risk of oral cancer in this study. Similar results have been previously reported. ${ }^{45}$

This study is not without limitations. First, the concentration of $\mathrm{PM}_{2.5}$ that is delivered to mouth is not known. Second, there were no $\mathrm{PM}_{2.5}$ exposure data before 2006. Nevertheless, those for $\mathrm{PM}_{10}$ were available from 1998 to 2011. The concentrations of $\mathrm{PM}_{2.5}$ from 2006 to 2011 were highly correlated. In addition, the concentrations of $\mathrm{PM}_{10}$ from 1998 to 2011 were highly correlated. Furthermore, there were high correlations between $\mathrm{PM}_{2.5}$ and $\mathrm{PM}_{10}$ from 2006 to 2011. These indicate that the participants might have been previously exposed to $\mathrm{PM}_{2.5}$ for quite some time. Therefore, we believe that high correlations could have also existed if there were historical data on $\mathrm{PM}_{2.5}$ exposure before 2006. The concentrations of $\mathrm{PM}_{2.5}$ and $\mathrm{PM}_{10}\left(\mu \mathrm{g} / \mathrm{m}^{3}\right)$ 
Table 4 Association of oral cancer with PM2.5 in Taiwanese men

\begin{tabular}{|c|c|c|c|c|c|c|}
\hline \multirow[b]{2}{*}{ Variables } & \multicolumn{3}{|l|}{ Model 1} & \multicolumn{3}{|l|}{ Model 2} \\
\hline & OR & $95 \% \mathrm{Cl}$ & $P$ values & OR & $95 \% \mathrm{Cl}$ & $P$ values \\
\hline \multicolumn{7}{|l|}{$\mathrm{PM}_{2.5}$} \\
\hline $\mathrm{PM}_{2.5}<26.74$ & 1 & - & - & 1 & - & - \\
\hline $26.74 \leq \mathrm{PM}_{2.5}<32.37$ & 0.91 & 0.75 to 1.10 & 0.332 & 0.91 & 0.75 to 1.11 & 0.342 \\
\hline $32.37 \leq \mathrm{PM}_{2.5}<40.37$ & 1.00 & 0.84 to 1.20 & 0.964 & 1.01 & 0.84 to 1.20 & 0.955 \\
\hline $\mathrm{PM}_{2.5} \geq 40.37$ & 1.42 & 1.17 to 1.73 & $0.001^{*}$ & 1.43 & 1.17 to 1.74 & $<0.0001^{*}$ \\
\hline \multicolumn{7}{|l|}{$\mathrm{PM}_{10-2.5}{ }^{\dagger}$} \\
\hline $\mathrm{PM}_{10-2.5}<18.88$ & 1 & - & - & 1 & - & - \\
\hline $18.88 \leq \mathrm{PM}_{10-2.5}<23.66$ & 0.95 & 0.80 to 1.11 & 0.511 & 0.95 & 0.81 to 1.12 & 0.517 \\
\hline $23.66 \leq \mathrm{PM}_{10-2.5}<32.42$ & 1.06 & 0.91 to 1.25 & 0.451 & 1.07 & 0.91 to 1.25 & 0.447 \\
\hline $\mathrm{PM}_{10-2.5} \geq 32.42$ & 1.10 & 0.89 to 1.37 & 0.367 & 1.10 & 0.89 to 1.36 & 0.373 \\
\hline \multicolumn{7}{|l|}{$\mathrm{SO}_{2}$} \\
\hline $\mathrm{SO}_{2}<2.96$ & 1 & - & - & 1 & - & - \\
\hline $2.96 \leq \mathrm{SO}_{2}<3.61$ & 0.82 & 0.67 to 1.01 & 0.064 & 0.83 & 0.67 to 1.02 & 0.070 \\
\hline $3.61 \leq \mathrm{SO}_{2}<4.43$ & 0.92 & 0.75 to 1.14 & 0.454 & 0.93 & 0.75 to 1.14 & 0.464 \\
\hline $\mathrm{SO}_{2} \geq 4.43$ & 0.86 & 0.70 to 1.07 & 0.171 & 0.86 & 0.70 to 1.07 & 0.174 \\
\hline \multicolumn{7}{|l|}{$\mathrm{O}_{3}$} \\
\hline $\mathrm{O}_{3}<28.69$ & 1 & - & - & 1 & - & - \\
\hline $28.69 \leq 0_{3}<30.97$ & 1.26 & 1.12 to 1.42 & $<0.0001^{*}$ & 1.26 & 1.11 to 1.42 & $<0.0001^{*}$ \\
\hline $30.97 \leq 0_{3}<33.79$ & 0.94 & 0.79 to 1.11 & 0.472 & 0.94 & 0.80 to 1.11 & 0.480 \\
\hline $\mathrm{O}_{3} \geq 33.79$ & 1.00 & 0.84 to 1.19 & 0.975 & 1.00 & 0.84 to 1.19 & 0.984 \\
\hline Age & 1.00 & 0.99 to 1.00 & 0.286 & 1.00 & 0.10 to 1.00 & 0.769 \\
\hline \multicolumn{7}{|l|}{ Betel chewing } \\
\hline Never & 1 & - & - & 1 & - & - \\
\hline Occasional & 1.01 & 0.81 to 1.28 & 0.905 & 0.88 & 0.70 to 1.12 & 0.306 \\
\hline Frequent & 1.74 & 1.39 to 2.18 & $<0.0001^{*}$ & 1.42 & 1.11 to 1.83 & $0.006^{*}$ \\
\hline Test for trend & $<0.0001^{*}$ & & & $0.0297^{*}$ & & \\
\hline \multicolumn{7}{|l|}{ Smoking } \\
\hline Never & - & - & - & 1 & - & - \\
\hline Occasional & - & - & - & 1.29 & 1.14 to 1.47 & $<0.0001^{*}$ \\
\hline Frequent & - & - & - & 1.40 & 1.15 to 1.70 & $0.001^{*}$ \\
\hline
\end{tabular}

Model 1: adjusted for $\mathrm{PM}_{10-25^{\prime}} \mathrm{SO}_{2^{\prime}} \mathrm{O}_{3^{\prime}}$ age, and betel quid chewing.

Model 2: adjusted for $\mathrm{PM}_{10-2.5^{\prime}} \mathrm{SO}_{2^{\prime}} \mathrm{O}_{3^{\prime}}$ age, betel quid chewing, and smoking.

${ }^{*} \mathrm{P}<0.05$.

$+\mathrm{PM}_{10}$ minus $\mathrm{PM}_{25}$.

$\mathrm{O}_{3}$, ozone; $\mathrm{PM}$, particulate matter; $\mathrm{SO}_{2}$, sulfur dioxide.

Table 5 Correlation of particulate matter 2.5 (PM2.5) concentrations from 2006 to 2011 using Spearman's analysis

\begin{tabular}{|c|c|c|c|c|c|c|}
\hline Year & 2006 & 2007 & 2008 & 2009 & 2010 & 2011 \\
\hline 2006 & 1.00 & $0.97^{*}$ & $0.96^{*}$ & $0.96^{*}$ & $0.95^{*}$ & $0.94^{*}$ \\
\hline 2007 & - & 1.00 & $0.98^{*}$ & $0.97^{*}$ & $0.97^{*}$ & $0.95^{*}$ \\
\hline 2008 & - & - & 1.00 & $0.98^{*}$ & $0.96^{*}$ & $0.94^{*}$ \\
\hline 2009 & - & - & - & 1.00 & $0.98 *$ & $0.96^{*}$ \\
\hline 2010 & - & - & - & - & 1.00 & $0.96^{*}$ \\
\hline 2011 & - & - & - & - & - & 1.00 \\
\hline
\end{tabular}

${ }^{*} \mathrm{P}<0.05$.

between 2006 and 2011 are shown in the online Supplementary tables 1 and 2, respectively.

\section{CONCLUSION}

In conclusion, higher concentrations of $\mathrm{PM}_{2.5}$ may be associated with increased risk of oral cancer in Taiwanese men. The mechanism through which this occurs is not clearly understood, hence further investigations are required.
Contributors Y-HC, S-WK, P-CK, S-JL and Y-PL designed the study and analyzed the data. Y-HC and DMT reviewed the manuscript. All the authors interpreted the data, drafted the manuscript and approved the final version of the manuscript.

Funding This research was funded by the Ministry of Science and Technology (MOST), Taiwan (MOST 105-2627-M-040-002, MOST 106-2627-M-040-002 and MOST 106-EPA-F-016-001).

Competing interests None declared. 
Patient consent Not required.

Ethics approval Institutional Review Board of Chung Shan Medical University Hospital.

Provenance and peer review Not commissioned; externally peer reviewed.

Open access This is an open access article distributed in accordance with the Creative Commons Attribution Non Commercial (CC BY-NC 4.0) license, which permits others to distribute, remix, adapt, build upon this work noncommercially, and license their derivative works on different terms, provided the original work is properly cited, appropriate credit is given, any changes made indicated, and the use is non-commercial. See: http://creativecommons. org/licenses/by-nc/4.0/.

\section{REFERENCES}

1 Warnakulasuriya S. Global epidemiology of oral and oropharyngeal cancer. Oral Oncol 2009:45:309-16.

2 Ferlay J, Soerjomataram I, Dikshit R, et al. Cancer incidence and mortality worldwide: sources, methods and major patterns in GLOBOCAN 2012. Int J Cancer 2015;136:E359-E386.

3 Chiang CJ, Chen YC, Chen CJ, et al. Cancer trends in Taiwan. Jpn J Clin Oncol 2010;40:897-904.

4 Ko YC, Huang YL, Lee CH, et al. Betel quid chewing, cigarette smoking and alcohol consumption related to oral cancer in Taiwan. J Oral Pathol Med 1995;24:450-3.

5 Blot WJ, McLaughlin JK, Winn DM, et al. Smoking and drinking in relation to oral and pharyngeal cancer. Cancer Res 1988;48:3282-7.

6 Miller CS, White DK. Human papillomavirus expression in oral mucosa, premalignant conditions, and squamous cell carcinoma: a retrospective review of the literature. Oral Surg Oral Med Oral Pathol Oral Radiol Endod 1996;82:57-68.

7 Sugerman PB, Shillitoe EJ. The high risk human papillomaviruses and oral cancer: evidence for and against a causal relationship. Oral Dis 1997;3:130-47.

8 Su CC, Lin YY, Chang TK, et al. Incidence of oral cancer in relation to nickel and arsenic concentrations in farm soils of patients' residential areas in Taiwan. BMC Public Health 2010;10:67.

9 Yuan TH, Lian I, Tsai KY, et al. Possible association between nickel and chromium and oral cancer: a case-control study in central Taiwan. Sci Total Environ 2011;409:1046-52.

10 Kaldor J, Harris JA, Glazer E, et al. Statistical association between cancer incidence and major-cause mortality, and estimated residential exposure to air emissions from petroleum and chemical plants. Environ Health Perspect 1984;54:319-32
11 Halonen Jl, Lanki T, Yli-Tuomi T, et al. Urban air pollution, and asthma and COPD hospital emergency room visits. Thorax 2008;63:635-41.

12 Kariisa M, Foraker R, Pennell M, et al. Short- and long-term effects of ambient ozone and fine particulate matter on the respiratory health of chronic obstructive pulmonary disease subjects. Arch Environ Occup Health 2015;70:56-62.

13 Beckerman BS, Jerrett M, Finkelstein $M$, et al. The association between chronic exposure to traffic-related air pollution and ischemic heart disease. J Toxicol Environ Health A 2012;75:402-11.

14 Stanek LW, Brown JS, Stanek J, et al. Air pollution toxicology--a brief review of the role of the science in shaping the current understanding of air pollution health risks. Toxicol Sci 2011;120:kfq367.

15 Ito K, Mathes R, Ross Z, et al. Fine particulate matter constituents associated with cardiovascular hospitalizations and mortality in New York City. Environ Health Perspect 2011;119:467-73.

16 Xing YF, Xu YH, Shi MH, et al. The impact of PM2.5 on the human respiratory system. J Thorac Dis 2016;8:E69.

17 Morakinyo OM, Mokgobu Ml, Mukhola MS, et al. Health outcomes of exposure to biological and chemical components of inhalable and respirable particulate matter. Int J Environ Res Public Health 2016;13:592.

18 Joint W and Organization WH. Health risks of particulate matter from longrange transboundary air pollution. 2006.

19 Fang GC, Wu YS, Chen JC, et al. Characteristic of polycyclic aromatic hydrocarbon concentrations and source identification for fine and coarse particulates at Taichung Harbor near Taiwan Strait during 2004-2005. Sci Total Environ 2006;366:729-38.

20 Paget-Bailly S, Cyr D, Luce D. Occupational exposures to asbestos, polycyclic aromatic hydrocarbons and solvents, and cancers of the oral cavity and pharynx: a quantitative literature review. Int Arch Occup Environ Health 2012;85:341-51.

21 Sørensen M, Autrup H, Møller P, et al. Linking exposure to environmental pollutants with biological effects. Mutat Res 2003;544:255-71.

22 Bernstein C, Prasad AR, Nfonsam V, et al. DNA damage, DNA repair and cancer. New Research Directions in DNA Repair InTech 2013.

23 Mehta M, Chen LC, Gordon T, et al. Particulate matter inhibits DNA repair and enhances mutagenesis. Mutat Res 2008;657:116-21.

24 Pavanello S, Clonfero E. Biological indicators of genotoxic risk and metabolic polymorphisms. Mutation Research/Reviews in Mutation Research 2000;463:285-308.

25 Turner MC, Jerrett M, Pope CA, et al. Long-term ozone exposure and mortality in a large prospective study. Am J Respir Crit Care Med 2016;193:1134-42.

26 Turner MC, Krewski D, Diver WR, et al. Ambient air pollution and cancer mortality in the cancer prevention study II. Environ Health Perspect 2017;125:087013 